Viso - Cadernos de estética aplicada Revista eletrônica de estética

ISSN 1981-4062

No 24, jan-jun/2019

http://www.revistaviso.com.br/
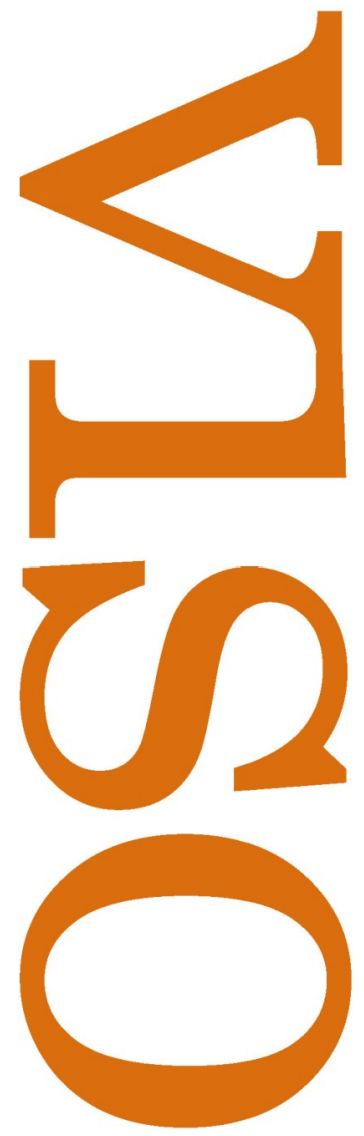

\title{
João Cabral de Melo Neto e o conceito de profundidade Cristiano Perius
}




\section{RESUMO}

\section{João Cabral de Melo Neto e o conceito de profundidade}

Este ensaio visa compreender a obra poética de João Cabral de Melo Neto a partir do conceito de profundidade, de Maurice Merleau-Ponty, utilizado como chave hermenêutica. Respeitando a autonomia de imagens que não se traduzem em conceitos, a fenomenologia é mobilizada de forma a acompanhar a experiência poética em seu próprio teor heurístico. É neste sentido que as características da poesia de João Cabral aparecem e são analisadas, como a antilírica, a metalinguagem e o engajamento social. Apesar da afinidade temática com a poesia de Carlos Drummond de Andrade, que retira a poesia das coisas, a semelhança é apenas aparente. A poesia de João Cabral compreende o conceito de profundidade, que atua por camadas, graus ou níveis de sedimentação linguística. A profundidade resulta do exercício de escavação com palavras que adquirem espessura semântica. Efeito do trabalho de mineração poética, o valor das imagens é descrito a partir de certas palavras, sempre as mesmas, mas que reverberam sobre as demais. A fim de descrever o profundo, as palavras escolhidas para a análise são: pedra, faca, cabra e cão.

Palavras-chave: João Cabral de Melo Neto - Maurice Merleau-Ponty - poesia - fenomenologia - ontologia

\section{ABSTRACT}

\section{João Cabral de Melo Neto and the Concept of Profundity}

This essay aims to study the poetic work of João Cabral de Melo Neto using the concept of depth, by Maurice Merleau-Ponty, employed as a hermeneutical key. Respecting the autonomy of images that cannot be reduced to concepts, phenomenology is used in order to accompany the poetic experience in its own heuristic content. It is in this sense that the characteristics of João Cabral's poetry appear and are analyzed; characteristics such as the anti-lyric, the metalanguage and the social engagement. Despite the thematic affinity with the poetry of Carlos Drummond de Andrade, whose poetry is inspired by things, the resemblance is only apparent. The poetry of João Cabral understands the concept of depth that operates by layers, degrees or levels of linguistic sedimentation. Depth results from the excavation exercise with words that acquire semantic thickness. As an effect of the work of poetic mining, the value of the images is described using specific words, always the same, words that stand out over the others. In this essay, the analyzed words are: stone, knife, goat and dog.

Keywords: João Cabral de Melo Neto - M. Merleau-Ponty - poetry - phenomenology - ontology 


\section{PERIUS, C. "João Cabral de Melo Neto e o conceito de profundidade”. In: Viso: Cadernos de estética aplicada, v. XII, n. 24 (jan-jun/2019), pp. 88-132.}

DOI: 10.22409/1981-4062/V24i/313

Aprovado: 19.01.2019. Publicado: 30.06.2019.

(C) 2019 Cristiano Perius. Esse documento é distribuído nos termos da licença Creative Commons Atribuição-NãoComercial 4.0 Internacional (CC-BY-NC), que permite, exceto para fins comerciais, copiar e redistribuir o material em qualquer formato ou meio, bem como remixá-lo, transformá-lo ou criar a partir dele, desde que seja dado o devido crédito e indicada a licença sob a qual ele foi originalmente publicado.

Licença: http://creativecommons.org/licenses/by-nc/4.0/deed.pt_BR

Accepted: 19.01.2019. Published: 30.06.2019.

(C) 2019 Cristiano Perius. This document is distributed under the terms of a Creative Commons Attribution-NonCommercial 4.0 International license (CC-BY-NC) which allows, except for commercial purposes, to copy and redistribute the material in any medium or format and to remix, transform, and build upon the material, provided the original work is properly cited and states its license.

License: http://creativecommons.org/licenses/by-nc/4.0/ 
a Alfredo Antonio Fernandes

E sem alma, corpo, és suave.

Carlos Drummond de Andrade

Em João Cabral de Melo Neto, a herança poética de Carlos Drummond de Andrade aparece desde o princípio. Na edição das obras completas, iniciada pela coletânea "Pedra do sono" (1940-1941), lê-se:

POEMA

Meus olhos têm telescópios

espiando a rua,

espiando minha alma

longe de mim mil metros.

Mulheres vão e vêm nadando

em rios invisíveis.

Automóveis como peixes cegos

compõem minhas visões mecânicas.

Há vinte anos não digo a palavra

que sempre espero de mim.

Ficarei indefinidamente contemplando

meu retrato eu morto.

\section{OS OLHOS}

Todos os olhos olharam:

o fantasma no alto da escada,

os pesadelos, o guerreiro morto,

a girl a forca e o amor.

Juntos os peitos bateram

e os olhos todos fugiram.

(Os olhos ainda estão muito lúcidos.)

Trata-se dos poemas inicias de João Cabral, ou seja, assinam a abertura da obra do poeta pernambucano. Desde os primeiros versos, impossível não lembrar o "Poema de sete faces", de Drummond, cujo movimento intencional inaugura uma poética do olhar. A metáfora dos olhos, em seu contexto semântico, não é um dispositivo acessório à produção de imagens. Pelo contrário, ligada ao corpo e sua dimensão afetiva, incorpora a composição poética de um homem tímido e reservado ao canto, discreto, dedicado à expectação do mundo (Cf. "O homem atrás do bigode/ é sério, simples e forte./ Quase não conversa./ Tem poucos, raros amigos/ o homem atrás dos óculos e do bigode." ${ }^{2}$ ). De João Cabral nós recebemos o mesmo estado de retraimento e introspecção: "Há vinte anos não digo a palavra/ que sempre espero de mim./ Ficarei indefinidamente 
contemplando/ meu retrato eu morto". É um estado de melancolia e de afetação sensível, que o final do "Poema de sete faces" chamou de comoção. O poeta é sensível ao mundo que vê em sua intimidade e afastamento, disposto a ver tudo e todos sem ser visto. Segundo o poema de João Cabral - note-se o título: "Os olhos" - "Todos os olhos olharam:/ o fantasma no alto da escada,/ os pesadelos, o guerreiro morto,/ a girl a forca o amor". O verso não tem sinal gráfico de pontuação, nem a forma gramatical da enumeração ( $A$ girl, a forca e o amor...). Indica, com a supressão, o volume infinito de objetos à vista, isto é, o movimento exterior ao cristalino dos olhos que se abrem ao campo visual. Depois da atividade ocular ininterrupta, exasperada, os olhos se cansam, fatigados, e fogem: "Juntos os peitos bateram/ e os olhos todos fugiram.// Os olhos ainda estão muito lúcidos". Lucidez e fatiga são uníssonos e ajustados em nome da tarefa de ver o mundo.

Qual será o estatuto da linguagem poética sob o signo do olhar? Uma das formas de responder a esta pergunta é através da epoché, segundo o jargão da fenomenologia. $O$ poeta opera a redução fenomenológica, isto é, suspende o que diz sobre o mundo para apresentá-lo em sua dimensão visível, sem predicação ou juízo. O "Poema de sete faces", de Drummond, já apresentava o caractere errático e não conceitual do olhar, anterior à reunião da linguagem: "O bonde passa cheio de pernas:/ pernas brancas pretas amarelas./ Para que tanta perna, meu Deus, pergunta meu coração./ Porém meus olhos/ não perguntam nada". Esta prática de epoché fenomenológica, como algo inerente ao dispositivo visual de produção poética, não é ingênua e acrítica, ao contrário, determina o trabalho contínuo e fatigante de olhar, bem visível nos versos de Drummond (do poema "No meio do caminho"): "Nunca me esquecerei desse acontecimento/ na vida de minhas retinas tão fatigadas". Trata-se do olhar em estado puro, rigorosamente mudo, agramatical ou pré-gramatical, cuja manifestação fundamental é a presença espontânea do sensível. Ora, o sensível é, segundo a filosofia de Merleau-Ponty, uma dimensão originária e irredutível a conceitos. Anterior ao sujeito e seus atos objetivantes, o sensível é a iniciação de base contínua e renovada aos fenômenos.

Evidentemente, a dinâmica não categorial do olhar, comum aos dois poetas, não é o único ponto em comum entre Drummond e Cabral. Além do poema "Quadrilha", que inspirou "Os três mal-amados", há todo um elã construído em torno de metáforas elementares, como a pedra e a água, que estruturam uma poética que troca nominalmente o adjetivo pelo substantivo. No interior da relação comunicante entre os poetas, extensiva, como se sabe, a vários outros escritores, está a meta-poesia, que nos interessa, inicialmente, analisar. Há em João Cabral visivelmente a edição de uma obra original, marcada pelo conceito de profundidade.

A partir dos itens a seguir: (1) "metalinguagem", (2) "antilírica", (3) "Cabral da peste", (4) "faca só lâmina", (5) "o conceito de profundidade" e (6) "cão sem plumas", compreenderemos como, a partir de imagens centrais, a saber, "pedra", "faca", "cabra" e "cão", a poesia de João Cabral descreve o profundo. A manifestação do profundo, 
segundo as imagens que iremos acompanhar, é explorada tanto na forma quanto no conteúdo, isto é, o autor faz confluir a semântica das palavras e o estilo ou a forma do discurso. Em outras palavras, a intencionalidade do poeta aparece tanto em sua metalinguagem, cujo objeto é a concepção poética, quanto nos títulos das coletâneas, que citam a pedra, o cão, o rio, a faca, etc. O resultado deste exercício de composição é, como veremos ao final do ensaio, o paradoxo de uma poesia que corta no lugar de pôr, utilizando a faca como instrumento de aumento. O mecanismo poético opera a "contrapelo", isto é, dá forma ao vazio e revela a arquitetura sólida/pétrea e mineradora do poeta engenheiro. A poesia de João Cabral não tem equivalentes. Mergulhemos no poema: "Psicologia da composição".

\section{Metalinguagem}

O poema é dividido em oito partes numeradas em romanos. A partir de uma sequência de I a VIII, salta aos olhos o deslocamento temporal que é bem mais do que um jogo de palavras. Vejamos como este deslocamento se apresenta:

I.

Saio de meu poema

como quem lava as mãos.

Algumas conchas tornaram-se,

que o sol da atenção

cristalizou; alguma palavra

que desabrochei, como a um pássaro.

Talvez alguma concha

dessas (ou pássaro) lembre,

côncava, o corpo do gesto

extinto que o ar já preencheu;

talvez, como a camisa

vazia, que despi.

II.

Esta folha branca

me proscreve o sonho,

me incita ao verso

nítido e preciso.

Eu me refugio

nesta praia pura

onde nada existe

em que a noite pouse. 


\author{
Como não há noite \\ cessa toda fonte; \\ como não há fonte \\ cessa toda fuga; \\ como não há fuga \\ nada lembra o fluir \\ de meu tempo, ao vento \\ que nele sopra o tempo. ${ }^{3}$
}

Parte I: "Saio de meu poema/ como quem lava as mãos." Parte II: "Esta folha branca"... O teor das duas partes é, a rigor, exterior ao poema, pois assinala, de um lado, o poema antes de ser começado, de outro, depois de concluído. Se acrescentamos agora as partes I e II - que pertencem ao processo de composição da obra e sua doação ao leitor -, ao poema propriamente dito, a ordem natural seria a seguinte: a folha branca (parte I), o poema (partes II a VII), a liberação ao público (parte VIII). Mas não é isso que acontece. Na primeira parte, o poema já foi publicado, isto é, está concluído. $\mathrm{Na}$ segunda, ele ainda não existe, só a folha branca, diante da qual o poeta espera que palavras surjam. Na verdade, todo o poema contempla a folha branca, uma vez que nada absolutamente será escrito. O poema é o registro do que não está escrito. Mais ainda, exposto em ordem inversa de como teria acontecido.

O que significa esta dupla inversão? Evidentemente, estamos diante de um paradoxo. Duplo, por sinal, uma vez que não há, via de regra, poema em folha branca, assim como a publicação de algo ainda não escrito. Ora, o sentido da inversão é muito claro. Vejamos, em primeiro lugar, a dimensão da temporalidade. O poeta espera, sem garantia de sucesso, que o leitor reviva a intencionalidade em que o poema foi escrito. O poeta teve uma intenção poética (tempo 1), mas teme pela forma. A formatividade do poema (tempo 2), que reforma/transforma/deforma a intenção da véspera, sofrerá uma vez mais a ação do tempo no futuro (tempo 3), onde o leitor tem parte:
III.
Neste papel pode teu sal virar cinza; pode o limão virar pedra; o sol da pele, o trigo do corpo virar cinza
(Teme, por isso, a jovem manhã sobre as flores da véspera). 


\author{
Neste papel \\ logo fenecem \\ as roxas, mornas \\ flores morais; \\ todas as fluidas \\ flores da pressa; \\ todas as úmidas \\ flores do sonho. \\ (Espera, por isso, \\ que a jovem manhã \\ te venha revelar \\ as flores da véspera). ${ }^{4}$
}

Note-se, no interior da terceira parte, a repetição em torno das palavras "temor" e "esperança". O elemento temporal é explícito: "véspera". O elemento estético também: "flor". Aquela intuição poética, aqueles versos que soavam tão somente como ideias, uma vez fixados no papel, não são mais os mesmos. E o que dirá o leitor? Borrão de poema, poema concluído, poema lido pelo leitor. Ontem, hoje, amanhã. Há uma ação profunda de camadas temporais que, superpostas entre si, dão ao poema a condição de algo em movimento. Tal movimento pode ser entendido no sentido de uma decalagem, indicando um déficit, mas também de êxito, quando atinge o objetivo. $O$ poeta teme o déficit, isto é, que a "jovem manhã" não conserve "as flores da véspera", mas também espera o sucesso, isto é, "que o sol da atenção cristalize alguma palavra, que desabrochou". A duração temporal atravessa o dia, a noite, a madrugada... Indica a elaboração estética contrária a teorias estéticas tanto da Antiguidade (teoria da inspiração divina) quanto do Romantismo alemão (teoria do gênio). A arte poética não é um dom inato, mas trabalho, disciplina intelectual diuturna. Ora, a qualidade de expressão difícil, sem dom inato ou expediente mágico para explicar a criação, aparece de maneira explícita na sexta parte do poema:

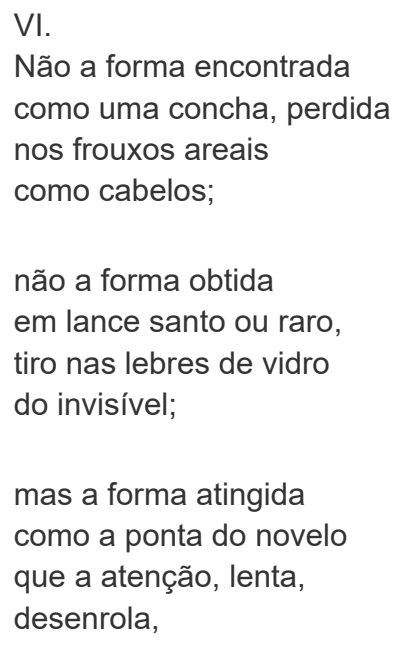


aranha; como o mais extremo

desse fio frágil, que se rompe

ao peso, sempre, das mãos

enormes. ${ }^{5}$

Note-se a fragilidade do poema que só aparece sob o signo do trabalho vigilante e prolongado do poeta. "As mãos enormes" representam a impossibilidade de sustentar a teia das palavras, pois que se rompe facilmente sob as mais diversas circunstâncias. As camadas temporais do poema corroboram o trabalho de expressão difícil, sem apoio formal ou técnico - como era de supor, no Parnasianismo, a sonoridade de um alexandrino, por exemplo. Mas isso não é tudo. O escalonamento temporal do poema tem outro sentido bem mais profundo do que os obstáculos no devir da criação. Há no poema um trabalho de mineração.

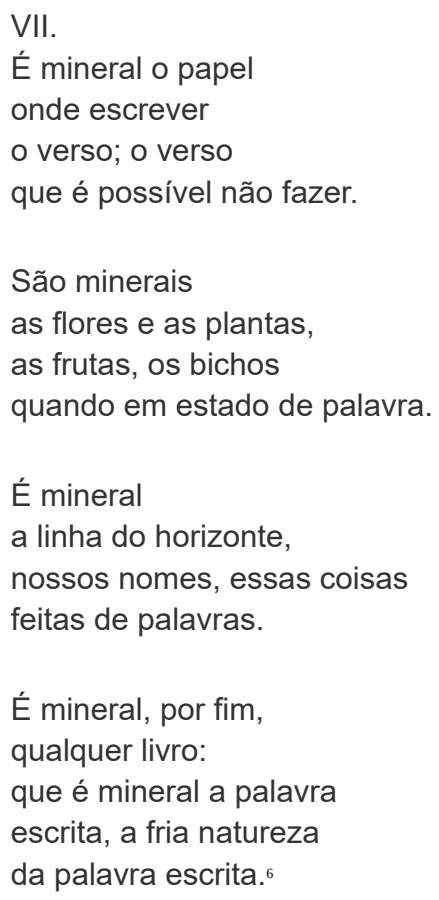

Em que sentido a palavra é mineral? Na medida em que petrifica o ser "em estado de palavra", isto é, dá substância ao mundo através da linguagem que enforma o pensamento. Segundo a fenomenologia de Merleau-Ponty, linguagem e pensamento, como puros relevos, são indiscerníveis. A essência ontológica das coisas é tributária das palavras em virtude do poder nominativo da linguagem. Que se lembre, a propósito, a carta de Heidegger sobre o humanismo, onde é dito que "a linguagem é a casa do ser". ${ }^{7}$ A razão disso está em que, como bem compreendeu o filósofo alemão, não há ser onde a palavra falta. $O$ nome das coisas é, na seara da linguagem, recurso memorial e vocativo, razão pela qual o anseio humano, na Arcádia homérica, era ouvir o nome proferido. Morrer jovem, mas ser lembrado, tal é a glória de Aquiles. Ora, a afirmação de Heidegger, na "Carta sobre o humanismo", aproxima-se da sabedoria grega uma vez que 
os poetas eram responsáveis pela transmissão da verdade, razão pela qual a poesia fora, naquele momento, pedagógica e prestigiada. Os poetas têm poder revelador, pois, artífices da palavra, chamam o não-ser à verdade da essência, invocando o ser do mundo com o nome. Embora a possibilidade do dizer não seja, em João Cabral, nada profética, guarda, no entanto, a qualidade mineral da pedra. Substantivo pedra. Substância que sustenta. Tautologia da linguagem que retira, senão coloca, os predicados das coisas nas palavras. $\mathrm{O}$ ato de mineração poética consiste em procurar, no fundo da terra, algo sólido e durável. A palavra, que o poeta encontra, é o fundamento que sustenta o poema. O dizer poético necessita deste cimento armado, sem o qual não tem substância. Ora, a linguagem é o pavimento sobre o qual o mundo aparece ou vem à frente. $\mathrm{O}$ mundo é produto da linguagem. Como a palavra funda, isto é, nomina, o mundo é aquilo que tem forma. A possibilidade poética é a possibilidade do ser.

Dito isto, passemos ao coração do diamante. A mineração poética pressupõe a escavação até a substância pétrea da palavra que promove o ser, conduzindo-o das trevas à luz, do esquecimento à memória. Mas não pensemos, em razão disso, que a estratégia do poema consiste em encontrar os substantivos que darão substância ao mundo. $\mathrm{O}$ ato de mineração poética, em "Psicologia da composição", está invertido:

VIII.

Cultivar o deserto

como um pomar às avessas.

(A árvore destila a terra, gota a gota; a terra completa cai, fruto!

\author{
Enquanto na ordem \\ de outro pomar \\ a atenção destila \\ palavras maduras). \\ Cultivar o deserto \\ como um pomar às avessas: \\ então, nada mais \\ destila; evapora; \\ onde foi maçã \\ resta uma fome; \\ onde foi palavra \\ (potros ou touros \\ contidos) resta a severa \\ forma do vazio. ${ }^{8}$
}


A inversão formal, que já tínhamos encontrado no arranjo sequencial das partes do poema, não é apenas temporal. É mais profunda. A estratégia do poeta consiste em retirar as palavras do poema até não poder mais, isto é, até chegar ao cúmulo da folha branca. O esvaziamento, assim, não é incondicionado, mas, absoluto. Ao invés de encher a folha de palavras, dela vai retirando palavra por palavra, até chegar à forma pura do vazio. A folha branca é, assim, clímax do poema, pois representa a possibilidade virtual de toda elaboração poética, em qualquer tempo e em qualquer mundo. Como a Biblioteca de Babel, de J. L. Borges, pensada ao contrário, a folha branca é possibilidade pura, diante da qual todos os poemas podem ser escritos. Não só os poemas efetivos, mas também os que se perderam, abortados, malogrados ou banidos. Trata-se, enfim, de um poema que recua, desde o título, da obra feita ao fazer da obra, como se o objetivo do poeta fosse surpreender o gesto criador em potência, anterior ao ato. A composição é visada em si mesma como objeto, onde o sujeito, a saber, o poeta, captura a possibilidade negativa de si mesmo, pois nega a folha branca que ele visa enquanto meta, escrevendo positivamente o que não pode ser escrito. $\mathrm{Na}$ metalinguagem de "Psicologia da composição", o poema transcende a realidade de poema e alcança a possibilidade poética. $\mathrm{O}$ alcance da metalinguagem não reside apenas aí. Em João Cabral, a consciência e a poesia andam lado a lado. Apesar de ser concomitante ao poético, o domínio metalinguístico modifica o elo entre as palavras e as coisas. As palavras descrevem as coisas, mas de outra maneira, pois são elas que estão em questão no poema. A reflexão sobre a linguagem visa às palavras em si mesmas, não obstante o seu poder bitransitivo. Malgrado o que são por essência, não designam estados de coisas. Assim como a folha branca é anterior ao poema, a palavra, neste domínio, é amorfa e indefinida. Vazia de forma e recuada ao domínio em que existe sem designar nada, é tão somente potência, fome, não ser:

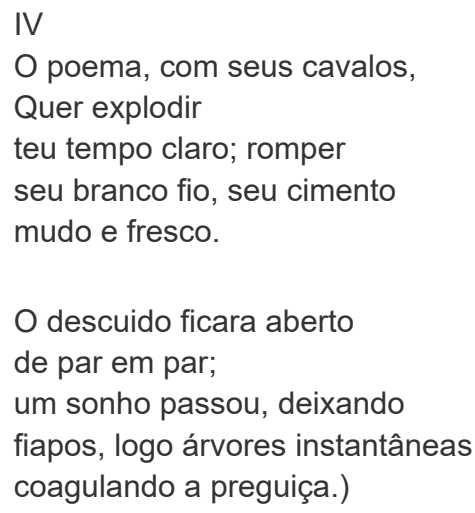




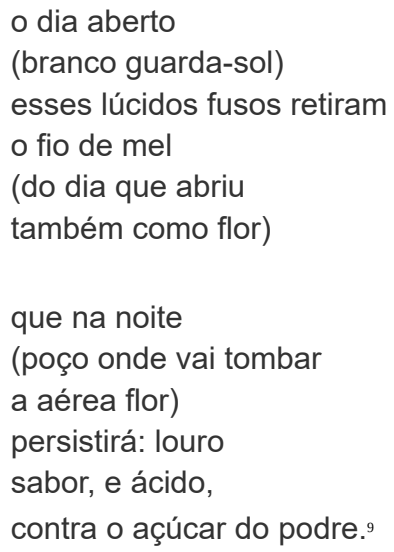

O ser do poema, reduzido à potência, limita-se à expectativa de sobrevivência das palavras que persistirão "contra o açúcar do podre", isto é, ao critério da necessidade. A folha branca é, assim, o poema em suspensão, a sombra ou a miragem de palavras que fixam os devaneios do poeta em sua luta com as palavras. Outro poema, "A lição de poesia", apresenta este estado de suspensão poética anterior às palavras:

\section{A LIÇÃO DE POESIA}

\section{1}

Toda a manhã consumida

como um sol imóvel

diante da folha em branco

princípio do mundo, lua nova.

Já não podia desenhar

sequer uma linha,

um nome, sequer uma flor

desabrochava no verão da mesa:

nem no meio-dia iluminado, cada dia comprado,

do papel, que pode aceitar, contudo, qualquer mundo.

2

A noite inteira o poeta

em sua mesa, tentando salvar da morte os monstros germinados em seu tinteiro.

Monstros, bichos, fantasmas de palavras, circulando, urinando sobre o papel, sujando-o com seu carvão. 
Carvão de lápis, carvão

da ideia fixa, carvão

da emoção extinta, carvão

consumido nos sonhos.

3

A luta branca sobre o papel que o poeta evita,

luta branca onde corre o sangue

de suas veias de água salgada.

A física do susto percebida

entre os gestos diários;

susto das coisas jamais pousadas

porém imóveis - naturezas vivas.

$E$ as vinte palavras recolhidas

nas águas salgadas do poeta

e de que se servirá o poeta

em sua máquina útil.

Vinte palavras sempre as mesmas de que conhece o funcionamento, a evaporação, a densidade

menor que a do $\mathrm{ar}{ }^{10}$

A folha branca reúne o poema que pode ou não vir a ser. Mas a poesia surge, após o signo do trabalho, segundo uma lógica de construção a partir de certas palavras escolhidas a dedo. No interior de "vinte palavras, sempre as mesmas" - núcleos semânticos em torno das quais gravita a máquina poética de João Cabral -, vamos examinar a "pedra", a "cabra", a "faca" e o "cão", quatro palavras apenas, mas que reverberam sobre as demais. Solange Rebuzzi, no livro O idioma de Cabral, arrola o seguinte elenco de palavras: 1. pedra, 2. cabra, 3. deserto, 4. faca, 5. seca, 6. lama, 7. rio, 8. água, 9. sol, 10. corpo, 11. cemitério, 12. caatinga, 13. morte, 14. dente, 15. osso, 16. fome, 17. mar, 18. engenho, 19. cana-de-açúcar, 20. sertão. ${ }^{11}$ Esta classificação é plausível, mas arbitrária. Benedito Nunes, extremo analista, não faz nenhum elenco ou lista, mas inclui as palavras "bala", "relógio" e "faca" ao círculo motor de "Uma faca só lâmina", uma vez que

os termos comparantes desempenham, por assim dizer, uma ação catalisadora na gestação das imagens; os símiles respectivos funcionam à maneira de esquemas da imaginação material, reguladores das analogias e das diferenças das séries metafóricas cumulativas geradas para descrever o que não é nem faca, nem bala, nem relógio.12

Trata-se de uma máquina de ressonâncias e de variações prismáticas a partir de objetos coisas e de objetos palavras em constante transformação ou devir. A ambivalência coisa/ 
palavra é relevante, pois considera a edição da forma linguística em sintonia com o ser do mundo. É neste sentido que os objetos pedra, cabra, faca e cão também são palavras, isto é, pertencem ao elo coisal e lexical das imagens. As palavras são poucas, mas muito é dito. Para entender este fenômeno de reverberação poética, em que "as vinte palavras, sempre as mesmas" reaparecem, utilizaremos o conceito de profondeur, de Merleau-Ponty, como recurso hermenêutico e instrumento analítico. O sensível contém o inteligível como gradiente em si mesmo, isto é, há, no sensível, profundidade, graus ou camadas de significação que, sobrepostas, interpostas, opostas, etc., dão uma dimensão de relevo ao que nele se encontra. Ora, as palavras também comportam a possibilidade de adquirir espessura semântica a partir da qual irão progressivamente designar outra coisa. O conceito de profundidade nos ajuda a compreender esta dinâmica da linguagem.

\section{Antilírica}

"Psicologia da composição" foi publicado em 1947, juntamente com dois outros poemas: "Fábula de Anfion" e "Antiode", dois anos após a coletânea Engenheiro, que apresenta, ao final, um poema imprescindível a quem deseja compreender a mineração do poeta. Vamos ao poema:

\section{PEQUENA ODE MINERAL}

Desordem na alma

que se atropela

sob esta carne

que transparece.

Desordem na alma

que de ti foge,

vaga fumaça

que se dispersa,

informe nuvem

que de ti cresce

e cuja face

nem reconheces.

Tua alma foge

como cabelos,

cunhas, humores,

palavras ditas

que não se sabe

onde se perdem

e impregnam a terra

com sua morte. 
Tua alma escapa

como este corpo

solto no tempo

que nada impede.

Procura a ordem

que vês na pedra:

nada se gasta

mas permanece.

Essa presença

que reconheces

não se devora

tudo em que cresce.

Nem mesmo cresce

pois permanece

fora do tempo

que não a mede,

pesado sólido

que ao fluido vence,

que sempre ao fundo

das coisas desce.

Procura a ordem

desse silêncio

que imóvel fala:

silêncio puro.

De pura espécie,

voz de silêncio,

mais do que a ausência

que as vozes ferem. ${ }^{13}$

À primeira vista, o poema confere ao mineral um teor anímico. Prova disso é a palavra "alma", que aparece quatro vezes no poema. É muito, se comparado ao vocábulo "pedra", que aparece uma só vez. Analisemos como estes dois vocábulos, "alma" e "pedra", estão qualificados. A razão para este exame é justa, uma vez que a alma domina o primeiro conjunto de seis estrofes. As outras seis vêm marcadas pelo domínio da pedra. A dominância é tal que o poema poderia ser dividido em dois. As grandezas métrica e rítmica acompanham o mesmo padrão de divisão, fazendo o poema rigorosamente metade alma, metade pedra.

Iniciemos pela primeira metade. "Desordem na alma/ que se atropela/ sob esta carne/ que transparece". Os versos da primeira estrofe qualificam a alma segundo o princípio clássico da imaterialidade. Mais importante, porém, é a situação de errância em que se encontra. A segunda estrofe acompanha o caráter fugaz da alma: "Desordem na alma/ que de ti foge,/ vaga fumaça/ que se dispersa". A fluidez da alma é tamanha que o poeta 
assinala sua dispersão evasiva: "informe nuvem/ que de ti foge,/ vaga fumaça/ que se dispersa". As estrofes seguintes complementam este estado de vacância e de imprevisibilidade: "Tua alma foge/ como cabelos,/ unhas, humores,/ palavras ditas// que não se sabe/ onde se perdem". Finalmente, a última estrofe arremata a condição de objeto movente, inapreensível, completamente à deriva: "Tua alma escapa/ como este corpo/ solto no tempo/ que nada impede".

A pedra, ao contrário, tem atributos sólidos: "Procura a ordem/ que vês na pedra:/ nada se gasta/ mas permanece". Está qualificada pelo reconhecimento, permanência, atemporalidade, peso, imobilidade, concretude: "Essa presença/ que reconheces/ não se devora/ tudo em que cresce.// Nem mesmo cresce/ pois permanece/ fora do tempo/ que não a mede,// pesado sólido/ que ao fluido vence,/ que sempre ao fundo/ das coisas desce" (grifo nosso). A diferença entre a pedra e a alma é evidente. Fluida e errante, a fugacidade da alma contrasta com a estabilidade da pedra. Esta concentra, aquela dissipa. Em certo sentido, podemos afirmar que a pedra é substantivo, a alma é adjetivo. $\mathrm{O}$ adjetivo é assessório, isto é, só existe em função do substantivo. Este caráter derivado é deletério, pois Ihe falta substância, solidez, tenacidade, firmeza. Ora, a mineração poética de João Cabral procura o substantivo. O que pode o adjetivo contra ele? Sabemos a resposta. Glória ao mineral, pois que o "fluido vence", "pesado sólido", "ao fundo das coisas desce". Esta avaliação revoga o status quo de grande parte da lírica clássica. Mais uma vez, estamos diante de uma inversão. A alma pode ser tudo, mas, por isso mesmo, é dúbia. A pedra, ao contrário, é sempre a mesma. A inversão de João Cabral está em que, ao contrário de toda uma tradição que vê a alma como profunda, ela é aérea, pois, imaterial e invisível, vai aonde quer. A pedra, ao contrário, não muda de lugar; em seu silêncio extremo, é espessa. A pedra é profunda. A alma é leviana, pois, como adjetivo retórico ou metafísico, gira em torno do corpo e flutua indefinidamente sem forma.

Não desprezemos, em nenhum momento, esta inversão. Pouco se ganha com a estética dos sentimentos elevados, requintados, perfumados, etc. Para João Cabral, mais vale o seco, o insípido. Sem alma, a pedra é profunda, pois serve de base ao mundo. A riqueza metafórica da pedra, em suas camadas de significação, é mais forte do que a alma. Eis aí a sobriedade poética, que alguns críticos chamaram de antilírica, que renuncia ao sentimentalismo adocicado e subjetivista para se ater ao objeto em sua própria experiência. A pedra não é dúbia, mas direta, incisiva:

\section{A EDUCAÇÃO PELA PEDRA}

Uma educação pela pedra: por lições; para aprender da pedra, frequentá-la; captar sua voz inenfática, impessoal (pela de dicção ela começa as aulas). A lição de moral, sua resistência fria ao que flui e a fluir, a ser maleada; 
a de poética, sua carnadura concreta; a de economia, seu adensar-se compacta: lições da pedra (de fora para dentro, cartilha muda), para quem soletrá-la.

Outra educação pela pedra: no Sertão (de dentro para fora, e pré-didática). No Sertão a pedra não sabe lecionar, e se lecionasse não ensinaria nada; lá não se aprende a pedra: lá a pedra, uma pedra de nascença, entranha a alma. ${ }^{14}$

Há, no poema, dois movimentos distintos de educação pela pedra. O primeiro movimento caracteriza-se pela ação direta da pedra sobre o homem. E o que ela ensina? Lições de economia, moral e poética. Sua "voz inenfática, impessoal" nos faz repetir o teor silencioso e impassível da pedra. Sua "resistência ao que flui" nos ensina a austeridade e a persistência, a moral obstinada de não amolecer em nenhuma circunstância. Resistência, força, vigor: virtudes inerentes à pedra. O segundo movimento dispensa a figura preceptora da pedra. Cessaram as lições, pois não são necessárias. A razão disso está em que, no interior do sertão nordestino, já se nasce sabendo. Entranhada no ser sertanejo, que outro poema descreveu como "incapaz de não se expressar em pedra" 15 , a convivência deixou marcas na pele. A caatinga, a seca, a fome, a morte, fazem parte do sertanejo. Morte e vida severina, Auto do frade, além do Rio Capibaribe, deixam claro o lugar do sertão como fonte privilegiada de imagens. ${ }^{16}$

Educação pela pedra apresenta um movimento que já estava em Drummond, cuja coletânea de 1961, Lição de coisas, demonstra em seu título. Benedito Nunes chama este movimento de "antilírico". Citemos uma passagem de João Cabral: a máquina do poema: "Essa tendência, com seu antilirismo, é consequente à neutralização dos sentimentos pessoais, em direção de uma poesia descritiva e objetivadora". ${ }^{17} \mathrm{Em}$ filosofia, a escola da fenomenologia traduz esta tendência pelo "retorno às coisas mesmas", isto é, a inclinação teórica que visa a nada antepor à experiência. Esse retorno, para Merleau-Ponty, chamar-se-á de "lógos do mundo estético", isto é, o reconhecimento de um solo originário, endereçado ao sensível, que não pode ser objeto de representação ou, em outras palavras, considerado na perspectiva de um sujeito transcendental. As coisas são, então, visadas nelas mesmas em seu lugar de doação. A iniciativa do poeta é colocar-se à escuta delas, sem submetê-las a ideias préestabelecidas.

Em poesia, Francis Ponge é considerado predecessor desta inclinação de dar dignidade às coisas. Em seu estudo sobre o autor de $\mathrm{O}$ partido das coisas, J-P. Sartre afirma:

O que nos é permitido de momento é desnudar as coisas de suas significações práticas. O que são essas "significações práticas" senão o reflexo sobre as coisas dessa ordem 
social que Ponge detesta? Há então em Ponge uma recusa de cumplicidade. Ele encontra nele palavras conspurcadas, "prontas", e fora dele objetos domesticados, aviltados; mediante um único movimento ele tentará desumanizar as palavras, procurando sob seu sentido de superfície a sua "espessura semântica", e desumanizar as coisas, raspando seu verniz de significações utilitárias. ${ }^{18}$

A avaliação de Sartre não é simples. Inscrita no ensaio que se chama "O homem e as coisas", o filósofo aponta para o trabalho de desvelamento ou descoberta contido em todo gesto criador. O retorno às coisas, que Drummond chamou de Lição de coisas, é resultado de um questionamento de teor fenomenológico. O que são as coisas? Esta pergunta filosófica, já colocada por Heidegger, não ocorre ao homem comum por uma razão muito simples: naturalmente, ninguém duvida das coisas. Por essa razão, segundo Husserl, a atitude natural não é filosófica, mas é uma fé perceptiva. A pergunta pela existência das coisas é filosófica e, no limite, metafísica, justamente porque elas estão revestidas de uma dimensão prática, que importa neutralizar. Ao recusar esta dimensão, o poeta pode então retirá-las do esquecimento do cotidiano. O cotidiano é uma frequentação viciada onde nada acontece. O cotidiano é (f)útil. Ora, o poeta recusa o cotidiano, pois, investido de função criadora, deve falar o não dito. O poeta engenha novas significações, pois recusa o linguageiro, isto é, o prosaico, não no sentido literário, que também é poético, mas no sentido do que é dito de forma corriqueira, sem valor heurístico. Por isso será preciso, diz Sartre, desumanizar as coisas e desumanizar as palavras. Será preciso, em outras palavras, mudar a perspectiva, causar estranhamento, admiração, assombro, estupor. Para Merleau-Ponty, a verdadeira fórmula da epoché é o espanto diante do mundo. Isso quer dizer que as coisas só terão espessura semântica, isto é, profundidade, quando a tradição for revogada em nome de uma nova forma de dicção do mundo. Ora, é esta nova dicção, de educação pela pedra, que o poema apresenta. Cf. verso 4: "pela de dicção ela começa as aulas" e 10: "para quem soletrála". Se o idioma da pedra é antilírico, é apenas na medida em que representa uma diferença em relação à perspectiva clássica, de teor subjetivista, habituada a florear os sentimentos. O idioma da pedra não é intimista, mas inscrito nas coisas em seu caráter objetivo.

\section{Cabral da peste}

No poema "O rio", de 1953, encontra-se uma identificação exemplar entre a pedra e a cabra:

Por trás do que lembro, ouvi de uma terra desertada, vaziada, não vazia, mais que seca, calcinada. 
De onde tudo fugia,

onde só pedra é que ficava,

pedras e poucos homens

com raízes de pedra, ou de cabra. ${ }^{19}$

Impossível não lembrar o clássico do forró brasileiro, "Asa branca". O teor dos versos de João Cabral encontra duas semelhanças com a canção de Luiz Gonzaga. Primeiro, a agressiva falta de água no sertão proporciona uma terra desolada em função do clima. Nas palavras de João Cabral: "terra desertada, vaziada, mais que seca, calcinada". Luiz Gonzaga: "a terra ardendo igual fogueira, braseiro, fornalha, nenhum pé de plantação, por falta de água perdi meu gado, morreu de sede meu alazão"... Segundo, a fuga dos homens em razão da seca. Segundo João Cabral, o sertão é o lugar "de onde tudo fugia, onde só pedra é que ficava, pedras e poucos homens". Luiz Gonzaga: "até mesmo a Asa branca bateu asas do sertão", "adeus Rosinha"... Ora, o clima árido, semi-desértico, que já estava identificado à pedra, recebe um novo símbolo: a cabra. O que torna a identificação possível são os predicados materiais da cabra. Rusticidade, resistência, igual ao camelo do deserto, a cabra é forte, não precisa de cuidados, não faz caprichos. Em "Poema(s) de cabra", da coletânea Quaderna (1956-1959), encontramos a concentração do maior número de imagens relacionadas ao objeto cabra:

\section{$\operatorname{POEMA}(S)$ DA CABRA}

Nas margens do Mediterrâneo não se vê um palmo de terra que a terra tivesse esquecido de fazer converter em pedra.

Nas margens do Mediterrâneo não se vê um palmo de pedra que a pedra tivesse esquecido de ocupar com sua fera.

Ali, onde nenhuma linha pode lembrar, porque mais doce, o que até chega a parecer suave serra de uma foice,

não se vê um palmo de terra por mais pedra ou fera que seja, que a cabra não tenha ocupado com sua planta fibrosa e negra.

1.

A cabra é negra. Mas seu negro não é o negro do ébano douto (que é quase azul) ou o negro rico do jacarandá (mais bem roxo). 


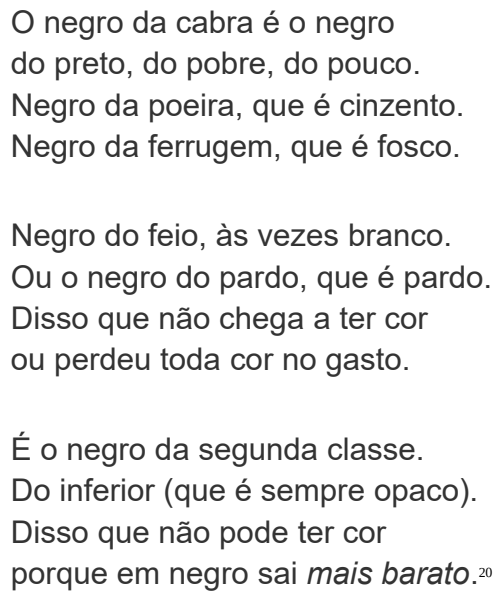

O poema tem nove seções. A primeira, sem numeração, está grafada em itálico. Nela, o poeta refere-se à paisagem íngreme e rochosa da costa do mediterrâneo - cuja imaginação poderia rapidamente associar-se à Córsega, mas também ao sul da Espanha, andaluz. A montanha exige, a quem a habita, atitude austera. Associada à fera, sublinha o lado bruto e selvagem da cabra. Aliado a esta imagem, os primeiros quartetos relacionam a cabra à faca. Através da serra e da foice, lembram o corte profundo e afiado da faca. Por fim, a cabra é associada à cor negra. Trata-se de três associações fundamentais: fera, faca e negro. Embora a faca seja uma das "vinte palavras, sempre as mesmas" 21 , isto é, uma das peças da maquinaria poética de João Cabral, a última imagem é mais importante. Como veremos adiante, o diagrama cromático do poema é chave para sua riqueza e profundidade.

Benedito Nunes aproxima o humor de João Cabral à cor negra: "Acre, contundente, desvendando o âmago visível das situações e exibindo o resíduo inumano, a essência cruel da existência, o grotesco e o absurdo das coisas, o humor de João Cabral é, como o humor negro, inimigo mortal do sentimentalismo que está sempre à espreita". ${ }^{22} \mathrm{Em}$ que medida o(s) "Poema(s) da cabra" e a citação acima condizem? Lembremos, em primeiro lugar, de Carlos Drummond de Andrade, a quem o chiste e o poema piada são frequentes. Em João Cabral, ao contrário de Drummond, o elemento trágico é apresentado sem o complemento cômico, alavancado pela fisionomia severa da cabra. Fria e impassível, a cabra não alimenta nenhum tipo de ironia. Ao contrário, evita o tom jocoso através de seu corpo severo e mudo.

A segunda seção do poema, grafada pelo número "1", inicia-se pela associação entre o negro da cabra e o negro das coisas: "não é o negro do ébano douto/ (que é quase azul) ou o negro rico/ do jacarandá (mais bem roxo)." Se o negro do ébano é azul e o negro do jacarandá é roxo, inversamente, "o negro da cabra é o negro/ do preto, do pobre, do pouco". O brilho do ébano e do jacarandá contrasta com a pobreza do negro sem lustre. O negro da cabra é cinzento, é branco: "Negro da poeira, que é cinzento./ Negro da ferrugem, que é fosco.// Negro do feio, às vezes branco./ Ou o negro do pardo, que é 
pardo./ Disso que não chega a ter cor/ ou perdeu toda cor no gasto". De um lado nós temos a versão majestosa do negro, representada pelo negror "douto" e "rico" de madeiras nobres, cada dia mais raras, de outro, a versão barata, puída, sem luxo, representada pela poeira e pela ferrugem. A qualidade de material desvalorizado é apresentada no último quarteto: "É o negro da segunda classe./ Do inferior (que é sempre opaco)./ Disso que não pode ter cor/ porque em negro sai mais barato". Qual é então a qualidade deste negro? Sem viço, desbotado, pardo, opaco, o negro da cabra é o negro por falta de cor. Não pensemos, contudo, que é pejorativo ou que pertence ao domínio mitológico do não-ser. Falta-lhe cor apenas no sentido de objeto usado ou gasto pela sobrecarga da lida. Furta-cor, o negro da cabra irradia:

2.

Se o negro quer dizer noturno o negro da cabra é solar. Não é o da cabra o negro noite. É o negro de sol. Luminar.

Será o negro do queimado mais que o negro da escuridão. Negra é do sol que acumulou. É o negro mais bem do carvão.

Não é o negro do macabro. Negro funeral. Nem do luto. Tampouco é o negro do mistério, de braços cruzados, eunuco.

É mesmo o negro do carvão. O negro da hulha. Do coque. Negro que pode haver na pólvora: negro de vida, não de morte. ${ }^{23}$

A terceira seção do poema reapresenta a associação entre a cabra e a pedra. Acompanhemos as imagens:

3.

O negro da cabra é o negro da natureza dela cabra. Mesmo dessa que não é negra, como a do Moxotó, que é clara.

O negro é o duro que há no fundo da cabra. De seu natural.

Tal no fundo da terra há pedra, no fundo da pedra, metal. 


\begin{abstract}
O negro é o duro que há no fundo
da natureza sem orvalho

que é a da cabra, esse animal

sem folhas, só raiz e talo,

que é a da cabra, esse animal

de alma-caroço, de alma córnea,

sem moelas, úmidos, lábios,

pão sem miolo, apenas côdea.
\end{abstract}

O que importa não é a cor, pois o adjetivo, para João Cabral, não tem valor. Dito melhor, apenas substantivado o adjetivo tem valor. Negror de cabra. Genitivo objetivo. O poeta visa à natureza objetiva da cabra, a partir da qual o adjetivo é qualificado. $O$ fundo da cabra é negro, assim como o fundo da pedra é metálico, segundo o poema. Substantivado, o adjetivo exprime a natureza da coisa. Ora, a natureza da cabra consiste em ser "animal sem folhas, só raiz e talo", não ter "moelas, úmidos, lábios", como "pão sem miolo, só casca". Não é em função de alguma teoria metafísica que a cabra ganha valor. Em outras palavras, o espírito da cabra, se espírito houver, não está em algum lugar inacessível, mas na superfície, na cor. Em sua fisionomia corporal ou visível, a cabra é profunda. A cabra é espessa. Essa é a razão pela qual o negro da pele aponta o esqueleto de fundo:

9.

O núcleo de cabra é visível debaixo do homem do Nordeste.

Da cabra lhe vem o escarpado

e o estofo nervudo que o enche.

Se adivinha o núcleo de cabra

no jeito de existir, Cardozo,

que reponta sob seu gesto

como esqueleto sob o corpo.

E é outra ossatura mais forte que o esqueleto comum, de todos; debaixo do próprio esqueleto,

no fundo centro de seus ossos.

A cabra deu ao nordestino

esse esqueleto mais de dentro:

o aço do osso, que resiste

quando o osso perde seu cimento. ${ }^{24}$

Mais forte que osso, a cabra é sólida, pois o "aço do osso resiste quando o osso perde seu cimento". Reflete o que há de mais fundo no homem, "debaixo do próprio esqueleto, no fundo centro de seus ossos". O fundo do osso, "esse esqueleto mais de dentro", é o núcleo da cabra: 
8.

O núcleo de cabra é visível

por debaixo de muitas coisas.

Com a natureza da cabra

outras aprendem sua crosta.

Um núcleo de cabra é visível

em certos atributos roucos

que têm as coisas obrigadas

a fazer de seu corpo couro.

A fazer de seu couro sola,

a armar-se em couraças, escamas:

como se dá com certas coisas

e muitas condições humanas.

Os jumentos são animais

que muito aprenderam com a cabra.

O nordestino, convivendo-a,

fez-se de sua mesma casta. ${ }^{25}$

Apta a enfrentar as dificuldades do sertão, a cabra inspira o sertão. $O$ desejo de ser cabra está na inclinação de fazer igual a ela, "como se dá com certas coisas e muitas condições humanas". A espessura da cabra alcança o que há de mais fundo nas coisas: "o núcleo da cabra é visível por debaixo de muitas coisas"; nos animais: "os jumentos são animais que muito aprenderam com a cabra"; nos homens: "o nordestino, convivendo-a, fez-se de sua mesma casta". A excelência da cabra é descrita sob as mais diversas circunstâncias. Ao fim e ao cabo, o poeta convence. A exuberância de imagens, através da longa extensão do poema, a riqueza em detalhes, o hermetismo, fazem da cabra um objeto privilegiado da reflexão e do trabalho mental do poeta. A cabra é a expressão de um pensamento longo e apurado sobre as coisas. Pensando em espiral, o poeta retoma as imagens e avança perfurando camadas, níveis, graus, sob as palavras e mesmo entre elas. É neste sentido que se pode dizer que a cabra é profunda, pois adquire espessura semântica por efeito da meditação poética que opera por repetição, variação e transformação das imagens. Prolongando-as, produz um campo de significação de espectro mais amplo, em périplo, fazendo aparecer, dentro da imagem, outra imagem. Por essa razão nós vemos nascer, no interior do escalonamento cromático da cabra, o negro que é negro, mas também cinza e branco. Tal movimento de perfuração, operado em abismo, depara-se, ao fim, com o paradoxo do oximoro. O núcleo da cabra, por ser a superfície, vai mais fundo que o osso. A profundidade ontológica e semântica da cabra nega o profundo, afirma o plano e faz dele o profundo. A superfície profunda que as imagens revelam é efeito da mineração poética, isto é, do gesto de escavar a superfície das palavras, revelando, de forma meditativa e aliterada, seu fundo. 
Cabra Cabral. Embora verdadeira, a aliteração não é motivação psicológica suficiente, pois o teor da cabra é objetivo. O corpo da cabra é eficaz. Ocorre, no entanto, de haver ambivalência entre o sentido semântico, que explora superfície fonética e lexical das palavras, e o ontológico, que explora o modo de doação das coisas enquanto fenômenos de percepção. Como bem observou Benedito Nunes, João Cabral dá atenção extrema à "natureza própria das coisas - quando em estado de palavras - e das palavras - quando em estado de coisas". ${ }^{26}$ A natureza do objeto encontra-se espelhada nas palavras em sentido onomatopeico, mas também de forma indireta e não evidente. A descoberta destas semelhanças pressupõe o trabalho poético de escavação das palavras.

Marta Peixoto observa que "há um acúmulo de consoantes nos versos: br, dr, tr, rd e pr, repetindo a camada fônica da equação pedra-cabra". ${ }^{27}$ Da parte de Francis Ponge, são conhecidos os estudos sobre o objeto esponja [éponge], cuja aliteração é éponge Ponge. Encontramos no poeta francês um verdadeiro tesouro de implicações semânticoontológicas entre as palavras e as coisas. Examinemos, a título de exemplo, um excerto de "A mesa" [table]:

Para se ter uma incontestável tável, basta tirar de incontestável seu insuportável incontes, de insuportável seu insuportável insupor. Tável não é senão um suporte, apenas mais do que este sufixo que atribui a qualquer uma possibilidade-de-ser de acordo com qualquer radical: sim, este ável, apoiado somente nesta coluna, o $T$ (que, pictograficamente, a designa). Assim, para te obter, ô Tável, basta marcar com o Tau da predestinação o sufixo que exprime a possibilidade-de-ser toda pura. Eis, portanto, a que magnificação nós chegamos. A mais sóbria, a mais simples; a mais singular também. Tável! Repete tável assim, leitor: assim, não a esquecerás mais. ${ }^{28}$

O poeta diz poeticamente que a letra T contém a mesa inscrita em sua forma. Table, em francês, deriva do latim popular tabula. A versão portuguesa vem do latim clássico, mensa. Nossa língua conservou, no entanto, a versão gálica em outros vocábulos, como tábua, tábula, távola, tabela, tablado, tablete, tabuleiro, etc. Ora, se tiramos o apoio da mesa, ela tomba. O verbo tombar vem de tombo, cair com barulho, pois, sem suporte insuportable -, a mesa deita, sucumbe, torna-se cama. Verdadeira [véritable] sustentação, o t da mesa precede, como radical, o sufixo incontestável [incontestable] que a palavra table apresenta em si mesma. O "tau da predestinação", em semi-cruz, retorna ao $t$ que se inscreve na tábua da mesa...

Como podemos ver neste exemplo, as palavras adquirem, como significantes, as mesmas propriedades que encontramos nas coisas. Admirador confesso de Francis Ponge, no poema "O sim contra o sim" João Cabral o caracteriza pela habilidade cirúrgica de "apalpar as coisas com os mil dedos da linguagem". ${ }^{29} \mathrm{Na}$ coletânea Pièces, Francis Ponge descreve da seguinte maneira o objeto cabra:

Por uma inflexão inteiramente natural, salmodiando desde então um pouco - e forçando a mão para agarrar a ocasião verbal pelos cabelos - damos a entender, queixo erguido, que a cabra [chèvre], próxima do cavalo [cheval], mas feminina com acento grave, é só 
uma modificação modulada, que não foge [cavale] nem desliza [dévale], mas de preferência escala, pela sua última sílaba, essas rochas abruptas, até a área de lançamento de voo, ao ninho suspenso da vogal muda. ${ }^{30}$

Observamos nesta passagem o tratamento que a cabra recebe do ponto de vista morfológico e lexical. Francis Ponge leva em conta o acento grave da palavra chèvre, a letra $V$, a letra $R$ e a letra $E$, ao final. $O$ acento lhe confere conotação feminina, se comparada ao cavalo [cheval]. Determinada a escalar a montanha, abriga-se no penhasco sobre as áreas de voo, isto é, exíguos espaços em plano, representados pela brevidade do "E", ao fim do nome, depois de passar pelo "R", de rocha, e pelo "V", de vale. Ora, o movimento fenomenológico de olhar o objeto não é menor. Ao tratar as palavras como coisas, o poeta não desconsidera a percepção. Resulta disso a técnica de construção polivalente, ocupada a revelar ao leitor o peso das coisas e o peso da linguagem. Ora, é exatamente a consideração deste duplo sentido que aproxima Francis Ponge e João Cabral. Ambos abandonam a teoria da inspiração e valorizam a elaboração atenta e programática. A ambos, poesia é engenharia, isto é, não é obra do acaso, não dá margem ao improviso, mas segue padrões de composição que produzem um idioma próprio a partir da objetividade da imagem. É neste sentido que se pode reconhecer, em João Cabral, o idioma da pedra e suas variantes:

Não nos surpreendemos encontrar, na obra de João Cabral, a pedra e seus derivados e/ ou afins, entre eles: caroço, osso, minério, casco, cimento, tijolo, cristal, em uma paisagem pedregosa que trabalha a noção de vida dura, e também a própria dor, em referência à "vida severina" que se faz tão "capaz de pedra" quanto a cabra. Pois é precisamente dentre os objetos componentes da imagística que define a cabra, muitos têm como sema comum a dureza, que se encontra dentro ou abaixo de uma superfície (pedra, raiz, talo, caroço, osso, esqueleto), ou formando uma proteção externa (côdea, crosta, couraça, escama), que percebemos o que vai determinar o idioma cabralino nesta construção. ${ }^{31}$

Severo Severino. De forma nada aparente, a aliteração está ligada ao destino profundo da cabra. Aliado às imagens da cabra, a vida severina é marcada pela prosperidade negativa de quem retira a vida da pedra.

\section{Faca só lâmina}

O lugar da faca na poética de João Cabral aparece em duas formas distintas. De forma indireta, no poema a seguir, e de forma direta, nas coletâneas Uma faca só lâmina e A escola das facas. Iniciemos pelo primeiro movimento: 
“A PALO SECO”

1.1

Se diz a palo seco

o cante sem guitarra;

o cante sem; o cante;

o cante sem mais nada;

se diz a palo seco

a esse cante despido

ao cante que se canta

sob o silêncio a pino.

1.2

O cante a palo seco

é o cante mais só:

é cantar num deserto

devassado de sol;

é o mesmo que cantar num deserto sem sombra

em que a voz só dispõe

do que ela mesma ponha.

1.3

O cante a palo seco

é um cante desarmado:

só a lâmina da voz

sem a arma do braço;

que o cante a palo seco sem o tempero ou ajuda tem de abrir o silêncio com sua chama nua.

1.4

O cante a palo seco

não é um cante a esmo:

exige ser cantado

com todo o ser aberto; 
é um cante que exige

o ser-se ao meio-dia,

que é quando a sombra foge

e não medra a magia.

2.1

O silêncio é um metal de epiderme gelada, sempre incapaz das ondas imediatas da água;

a pele do silêncio pouca coisa arrepia:

o cante a palo seco

de diamante precisa.

2.2 .

O silêncio é metal pesado, é um líquido denso que jamais colabora nem ajuda com ecos;

mais bem, esmaga o cante e afoga-o, se indefeso: a palo seco é um cante submarino ao silêncio.

2.3.

Ou o silêncio é levíssimo

é líquido sutil

que se coa nas frestas

que no cante sentiu;

o silêncio paciente vagaroso se infiltra, apodrecendo o cante de dentro, pela espinha.

2.4

Ou o silêncio é uma tela que difícil se rasga e que quando se rasga não demora rasgada; 
quando a voz cessa, a tela se apressa em se emendar: tela que fosse de água, ou como tela de ar.

3.1.

A palo seco é o cante de todos mais lacônico, mesmo quando pareça estirar-se um quilômetro:

enfrentar o silêncio assim despido e pouco tem de forçosamente deixar mais curto o fôlego.

3.2.

A palo seco é o cante de grito mais extremo: tem de subir mais alto que onde sobre o silêncio;

é cantar contra a queda, é um cante para cima, em que se há de subir cortando, e contra a fibra.

3.3.

A palo seco é o cante de caminhar mais lento: por ser a contrapelo, por ser a contravento;

é cante que caminha com passo paciente: o vento do silêncio tem a fibra de dente.

3.4.

A palo seco é o cante que mostra mais soberba; e que não se oferece: que se toma ou se deixa; 
cante que não se enfeita,

que tanto se lhe dá;

é cante que não canta,

cante que aí está.

4.1.

A palo seco canta

o pássaro sem bosque,

por exemplo: pousado

sobre um fio de cobre,

a palo seco canta

ainda melhor esse fio

quando sem qualquer pássaro

dá o seu assovio.

4.2.

A palo seco cantam

a bigorna e o martelo,

o ferro sobre a pedra,

o ferro contra o ferro;

a palo seco canta

aquele outro ferreiro:

o pássaro araponga

que inventa o próprio ferro.

4.3.

A palo seco existem situações e objetos:

Graciliano Ramos

desenho de arquiteto,

as paredes caiadas,

a elegância dos pregos,

a cidade de Córdoba,

$o$ arame dos insetos. 
4.4.

Eis uns poucos exemplos

de ser a palo seco,

dos quais se retirar

higiene ou conselho:

não o de aceitar o seco

por resignadamente,

mas de empregar o seco

porque é mais contundente. ${ }^{32}$

A primeira atribuição da faca é desempenhar uma função crítica, pois denota a preocupação do poeta quanto à forma. De modo intencional, a faca é responsável por "incitar o verso nítido e preciso" 33 , isto é, o verso antilírico, sem pompa, figuras, recursos de estilo. A vocação crítica conduz o poeta a cortar todo tipo de excesso. Reduzido ao mínimo essencial, a lâmina da faca representa o estado de síntese máxima. Essa política de corte, como recurso formal "minimalista", mobiliza o lirismo ao contrário, "a contrapelo", "a palo seco". Mergulhemos nas imagens do poema.

Em termos quantitativos, as palavras que mais aparecem são: silêncio (12 vezes), palo seco (18) e cante (27). Chama a atenção o número elevado de repetições. O poeta compara a poesia ao palo seco - formato musical precursor ao flamenco, executado sem acompanhamento de violão: "Se diz a palo seco/ o cante sem guitarra;/ o cante sem; o cante;/ o cante sem mais nada". A primeira estrofe já apresenta o signo da faca disposta a cortar qualquer tipo de acréscimo retórico à forma poética. No entanto, a presença da faca não é explícita, mas, nuançada: "O cante a palo seco/ é um cante desarmado:/ só a lâmina da voz/ sem a arma do braço". Árido, seco, o lirismo é aí esvaziado, despojado de música de fundo. "O cante a palo seco/ é o cante mais só:/ é cantar num deserto/ devassado de sol". O esvaziamento de elementos adicionais ao canto é tal que só o silêncio o rivaliza: "Enfrentar o silêncio/ assim despido e pouco"; "a palo seco é um cante/ submarino ao silêncio"; "A palo seco é o cante/ de grito mais extremo:/ tem de subir mais alto/ que onde sobe o silêncio". O destino da faca é o de cortar até não poder mais, até deixar a voz muda, até deixar de ser canto: "cante que não se enfeita, é cante que não canta,/ cante que aí está”. Ameaçado pela faca, a voz retorna ao silêncio.

\footnotetext{
Até o dia em que essa lâmina abandone seu deserto, encontre o avesso do nada, tenha enfim seu objeto.

Até o dia em que essa lâmina, essa agudeza desperta, ache, no avesso do nada, o uso que as facas completa. ${ }^{34}$
} 
O significado da faca é duplo. A faca é primeira em relação a outras imagens. A razão disto está em que, cortando até o fim, a faca revela-se, pois resta o vazio, o nada, como efeito da lâmina. Isso quer dizer que a faca é o objeto do poema, uma vez que não há outro objeto. Este outro é fundamental, pois, se houver "no avesso do nada, o uso que as facas completam", então ela deixará de ser objeto, aparecendo algo que não seja o vazio. Trata-se de uma tensão, jamais resolvida, entre linguagem e metalinguagem. $\mathrm{O}$ teor da faca é ambíguo, pois toma a forma poética por objeto, mas o contrário também é verdadeiro, pois não é só metalinguístico. Em João Cabral, a faca é onipresente. Representa a consciência formal do poeta, quando é objeto de metalinguagem e, ao mesmo tempo, assume outros significados.

Em outras palavras, o dispositivo crítico da faca não é apenas formal. É mais profundo. Associado ao movimento de mineração, o poeta deposita "no fio agudo de facas/ o fio frágil da vida". ${ }^{35}$ (PF,163) A profundidade da faca faz aparecer, sob a superfície daquilo que corta, o fundo da coisa. Em Uma faca só lâmina (1955), lê-se: "Seja bala, relógio/ ou a lâmina colérica,/ é contudo uma ausência/ o que esse homem leva. [...] E mais surpreendente/ ainda é sua cultura:/ medra não do que come/ porém do que jejua" ${ }^{36}$ Mais uma vez, estamos diante de uma inversão. ${ }^{37} \mathrm{O}$ alimento existe em função da fome que se deseja saciar. Saciado, o corpo esquece a fome, que é sua condição inicial. Tal como o mito de Sísifo, o saciar-se é efêmero, pois o estado de fome retorna. O caminho da imagem é inverso à ordem natural, pois vai do alimento à fome. Cortando arestas, o interesse da faca é ir direto ao fundo.

Mas não pensemos que o corte da faca retira, isto é, deixa menor seu objeto. Ao contrário, trata-se de uma ferramenta de aumento. A lâmina não diminui o que corta, mas aumenta. Cortando até o fim, isto é, até o fundo, resta o abismo operado por ela. O abismo depende da amplitude da faca. Ora, há situações negativas que "ganham a fome e o dente da faca" ${ }^{38}$, isto é, têm relevo enquanto objetos não aparentes. A fragilidade da vida, o deserto, a fome, o vazio, a ausência, o silêncio, a falta, entre outras imagens que aí aparecem, decorrem do crivo poético de dizer o profundo. O silêncio precisa ser dito para ser afirmado, do contrário pode passar despercebido. A faca de aumento revela "a contrapelo", em sentido invertido, o "antes" da coisa, isto é, seu estado profundo. Sinal de que a faca, a pedra, a cabra, ganham espessura, isto é, profundidade, através da reverberação metafórica que, de forma repetida e aliterada, explora a superfície das palavras até chegar à essência das coisas e vice-versa.

\section{O conceito de profundidade}

No final do poema "Festa na casa-grande", que encerra a coletânea Dois parlamentos, lê-se: 


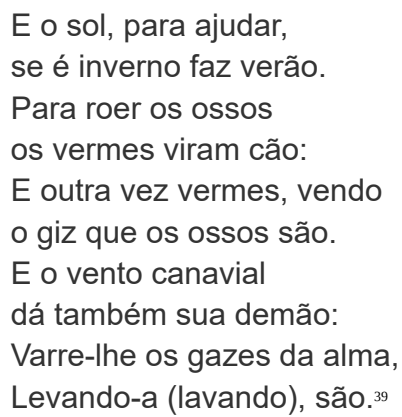

Há três imagens dominantes no poema: 1) o sol, que transforma o inverno em verão; 2) os vermes, que a fim de roer os ossos viram cão; 3) o vento, que varre a alma dos ossos. O inverno passa a verão. Os vermes passam a cão (e novamente a vermes "vendo o giz que os ossos são"). O vento varre os ossos. Nos três exemplos encontramos o fenômeno de transubstanciação. O jogo metafórico desloca o referente de modo que a passagem ao novo sentido é completa, na primeira e na terceira imagem, e incompleta, na segunda. A bi-dimensionalidade da metáfora é a possibilidade de assumir uma significação ambígua e nuançada, sem fechar-se em um dos termos, como o "vermecão".

Segundo Merleau-Ponty, o conceito de carne marca a reversibilidade e a bidimensionalidade do sensível. Para o senso-comum, o visível é apenas o que vemos. Trata-se de uma concepção equivocada, uma vez que assume a forma do empirismo ou do intelectualismo para explicar a percepção. O empirismo considera a percepção como o resultado de uma relação imediata com o mundo, ao passo que o intelectualismo a considera como produto de uma consciência transcendental. A percepção, segundo o filósofo, é uma presença a fenômenos inesgotáveis e irredutíveis ao pensamento. Vemos o "real", isto é, o campo de objetos que resultam da neutralização da subjetividade em nome de algo invariável. O que não vemos é a totalidade dos modos de doação dos fenômenos. O que não vemos, segundo Merleau-Ponty, é o invisível. Mas não se trata de algo oculto em não se sabe qual lugar inacessível ou metafísico. O invisível é do visível, isto é, inscrito nele:

O invisível não é o contraditório do visível: o visível possui, ele próprio, uma membrura de invisível, e o invisível não aparece senão nele, é o Nichturpräsentierbar que me é apresentado como tal no mundo - não se pode vê-lo aí, e todo o esforço para aí vê-lo o faz desaparecer, mas ele está na linha do visível, é a sua pátria virtual, inscreve-se nele em filigrana. ${ }^{40}$

Em outras palavras, o profundo não é o que não vemos. Profundo é o visível, pois assume espessura, níveis, camadas. Essa é a razão pela qual, em $O$ visível e o invisível, Merleau-Ponty diz: "Mas é próprio do visível ser a superfície de uma profundidade inesgotável". ${ }^{41}$ A atividade expressiva do poeta visa o profundo, isto é, a gama de relações paradoxais e invisíveis que acompanha a percepção: "A única maneira de 
concordar com a nossa percepção de fato, de corresponder ao que, no seu interior, ela nos leva a pensar, aos paradoxos de que é feita, é se ajustar a esses enigmas figurados, a coisa e o mundo, cujo ser e verdade maciços fervilham de pormenores incompossíveis". ${ }^{42}$ Examinaremos, no excerto a seguir, este paradoxo:

O cassaco de engenho

de longe é branco ou negro:

De perto é que se vê que é amarelo mesmo.

O cassaco de engenho

é amarelo sempre:

Mas do amarelo inchado

que é verde levemente.

Deste verde amarelo

em que o azul não entra

e que não fosse nele

se diria doença.

Um verde especial,

espécie de auriverde,

só dele, branco ou negro,

de receita só dele. ${ }^{43}$

A superfície cromática do poema é peculiar. O branco, o negro e o verde não são cores específicas, mas variações de amarelo. Efeito de sua densidade, o amarelo adquire diferença tonal a partir do leque de lugares e de situações em que é visto. De longe é branco ou negro. De perto é amarelo que, intensificado, é verde-amarelo ou auriverde. A percepção da cor não é objetiva, mas nuançada a partir da profundidade do visível.

Na coletânea Educação pela pedra, encontra-se um poema dedicado ao amarelo:

\section{OS REINOS DO AMARELO}

A terra lauta da Mata produz e exibe um amarelo rico (se não o dos metais): o amarelo do maracujá e os da manga, o do oiti-da-praia, do caju e do cajá; amarelo vegetal, alegre de sol livre, beirando o estridente, de tão alegre, e que o sol eleva de vegetal a mineral, polindo-o, até um aceso metal de pele. Só que fere a vista um amarelo outro, e a fere embora baço (sol não o acende): amarelo aquém do vegetal, e se animal, de um animal cobre: pobre, podremente.

2.

Só que fere a vista um amarelo outro:

se animal, de homem: de corpo humano; 
de corpo e vida; de tudo o que segrega

(sarro ou suor, bile íntima ou ranho),

ou sofre (o amarelo de sentir triste,

de ser analfabeto, de existir aguado):

amarelo que no homem dali se adiciona

o que há em ser pântano, ser-se fardo.

Embora comum ali, esse amarelo humano

ainda dá na vista (mais pelo prodígio):

pelo que tardam a secar, e ao sol dali,

tais poças de amarelo, de escarro vivo. ${ }^{44}$

Impossível evitar a temática social subjacente ao poema. Esta dimensão é visível a partir da relação do amarelo com o sol predominante no sertão, cujo êxodo rural, a fome e a sede já foram temas de mais de um artista engajado. É neste sentido também que o amarelo dialoga com o quadro pictórico. A temática social é retratada de forma verbal e visual. Basta, para o exame da primeira forma, examinar seu léxico: pobre, podremente, suor, bile, ranho, sofre, triste, analfabeto, pântano, escarro, fardo..." Ipsis litteris, tal como está, ou traduzido, o diagrama das imagens é o seguinte: pobreza, suor, sofrimento, tristeza, analfabetismo, trabalho pesado, ferida, escarro, ranho, podridão... Este conjunto de imagens está espelhado pela disposição visual, quase pictórica, do amarelo que, enquanto tal, arquiteta o poema. São dois amarelos. O primeiro marca a opulência de minerais e vegetais que reluzem o amarelo do ouro, do maracujá, da manga, do oiti, do caju, do cajá... O teor faustuoso é explícito: "um amarelo rico; beirando o estridente, de tão alegre...". No entanto, ocorre que este amarelo é ofuscado por outro amarelo, não reluzente, nem saboroso, mas apodrecido, deteriorado. $\mathrm{O}$ amarelo do segundo grupo é humano, ao passo que o do primeiro grupo é vegetal e mineral. A natureza pode até ser pródiga, mas a substância humana não tem a mesma sorte. $\mathrm{O}$ teor social, que identifica o amarelo do segundo grupo ao homem analfabeto, sofredor e miserável, é incontestável. A preocupação com o social não escapa ao poeta, ao contrário, trata-se de "um projeto exemplar na poesia de língua portuguesa, marcado por uma absoluta, e até exacerbada, consciência dos mecanismos da linguagem poética, passando por uma negação do poético em benefício de uma observação aguda dos problemas sociais mais graves do Brasil". ${ }^{45}$ Esta observação é importante para colocar em igual medida o plano metalinguístico e o plano social, isto é, as considerações abstratas sobre a linguagem e as considerações concretas sobre o mundo. Adalberto Müller, no prefácio a João Cabral: a máquina do poema, afirma que "Benedito Nunes demonstra lucidamente que um livro como $O$ cão sem plumas contém ao mesmo tempo os elementos de 'temas sociais' e de 'metapoesia', de 'participação' e 'lógica composicional'. As 'duas águas' deveriam ser assim encaradas como duas faces de uma mesma poesia". ${ }^{46}$ O poema utiliza a cor amarela para revelar as contradições sociais do Brasil. Ora, não se pode, via de regra, exigir compromisso social do amarelo. De onde então o talismã da cor, a peculiaridade de revelar o mundo? Nas notas de O visível e o invisível, Merleau-Ponty diz:

A particularidade da cor, do amarelo, e a universalidade não estão em contradição, pois são juntos a própria sensorialidade: é pela própria virtude que a cor, o amarelo, se dá ao 
mesmo tempo como certo ser e uma dimensão, a expressão de todo o ser possível. [...] A percepção não é percepção de coisas primeiro, mas de elementos (água, ar...), de raios do mundo, de coisas que são dimensões, que são mundos, deslizo sobre esses "elementos" e eis-me no mundo, deslizo do "subjetivo" para o Ser. ${ }^{47}$

O que faz o amarelo receber papel constitutivo é o poder generalizador que ele adquire em função da percepção sensível. O amarelo ultrapassa a condição de cor particular e mobiliza a imaginação de forma a estabelecer pivôs, suportes, em torno dos quais as significações gravitam. Aquele que percebe não está só no aqui e agora, mas se transporta virtualmente sobre outras percepções possíveis. A profundidade da cor está no sensível capaz de modular, com a participação do imaginário, o semelhante, em primeiro lugar, o dissemelhante, em segundo, e, finalmente, todas as coisas. Pela sua condição sensível, o amarelo deixa de ser amarelo e passa a símbolo. Há um espaço de vacância em torno da cor, pois adquire envolvimento subjetivo em sentido psicológico, permitindo a generalidade e a multiplicidade de perspectivas. Em outras palavras, se o amarelo é profundo, é porque não está dado de forma objetiva. Por ser sensível, incorpora a percepção de camadas, graus, contradições. Segundo Merleau-Ponty: "O que se chama um visível é, dizíamos, uma qualidade prenhe de uma textura, a superfície de uma profundidade, o corte de um ser maciço, o grão ou o corpúsculo levado por uma onda de Ser" ${ }^{48}$ A profundidade do sensível é tamanha que, segundo o filósofo, "não há mundo inteligível, há mundo sensível". 49 O sentido desta afirmação é extraordinário. 0 inteligível é um desdobramento do sensível, pois como ser de latências, o sensível é profundo.

O poema a seguir reflete diretamente o conceito de profundidade:

\author{
DE UM AVIÃO \\ 1 \\ Se vem por círculos na viagem \\ Pernambuco - Todos-os-Foras. \\ Se vem numa espiral \\ da coisa à sua memória. \\ O primeiro círculo é quando \\ o avião no campo do lbura. \\ Quando tenso na pista \\ o salto ele calcula. \\ Está o Ibura onde coqueiros, \\ onde cajueiros, Guararapes. \\ Contudo já parece \\ em vitrine a paisagem.
}


$\mathrm{O}$ aeroporto onde o mar e mangues,

onde o mareiro e a maresia.

Mas ar condicionado,

mas enlatada brisa.

De Pernambuco, no aeroporto, a vista já pouco recolhe.

É o mesmo, recoberto,

porém, de celuloide.

Nos aeroportos sempre as coisas

se distanciam ou celofane.

No do lbura até mesmo

a água doída, o mangue.

Agora o avião (um saltador)

caminha sobre o trampolim.

Vai saltar-me de fora

para mais fora daqui.

No primeiro círculo, em terra de Pernambuco já me estranho. Já estou fora, aqui dentro deste pássaro manso.

\section{2}

No segundo círculo, o avião vai de gavião por sobre o campo.

A vista tenta dar

um último balanço.

A paisagem que bem conheço por tê-la vestido por dentro, mostra, a pequena altura coisas que ainda entendo.

Que reconheço na distância de vidros lúcidos, ainda: eis o incêndio de ocre que à tarde queima Olinda;

eis todos os verdes do verde, submarinos, sobremarinos: dos dois lados da praia estendem-se indistintos;

eis os arrabaldes, dispostos numa constelação casual; eis o mar debruado pela renda de sal; 
e eis o Recife, sol de todo

o sistema solar da planície:

daqui é uma estrela

ou uma aranha, o Recife,

se estrela, que estende seus dedos, se aranha, que estende sua teia:

que estende sua cidade

por entre a lama negra.

(Já a distância sobre seus vidros

passou outra mão de verniz:

ainda enxergo o homem,

não mais sua cicatriz).

3

O avião agora mais alto

se eleva ao círculo terceiro,

folha de papel de seda

velando agora o texto.

Uma paisagem mais serena,

mais estruturada, se avista:

todas, de um avião,

são de mapa ou cubistas.

A paisagem, ainda a mesma, parece agora noutra língua: numa língua mais culta,

sem vozes de cozinha.

Para língua mais diplomática

a paisagem foi traduzida:

onde as casas são brancas

e o branco, fresca tinta;

onde as estradas são geométricas

e a terra não precisa limpa

e é maternal o vulto

obeso das usinas;

onde a água morta do alagado passa a chamar-se de marema e nada tem de gosma,

morna e carnal, de lesma.

Se daqui se visse seu homem, homem mesmo pareceria:

mas ele é o primeiro

que a distância eneblina 
para não corromper, decerto, o texto sempre mais idílico que o avião dá a ler de um a outro círculo.

4

Num círculo ainda mais alto o avião aponta pelo mar.

Cresce a distância com seguidas capas de ar.

Primeiro, a distância se põe a fazer mais simples as linhas; os recifes e a praia com régua pura risca.

A cidade toda é quadrada em paginação de jornal, e os rios, em corretos meandros de metal.

Depois, a distância suprime por completo todas as linhas; restam somente cores justapostas sem fímbria:

o amarelo da cana verde, o vermelho do ocre amarelo, verde do mar azul, roxo do chão vermelho.

Até que num círculo mais alto essas mesmas cores reduz: à sua chama interna, comum, à sua luz,

que nas cores de Pernambuco é uma chama lavada e alegre, tão viva que de longe sua ponta ainda fere,

até que enfim todas as cores das coisas que são Pernambuco fundem-se todas nessa luz de diamante puro. 
Penetra por fim o avião pelos círculos derradeiros. A ponta do diamante perdeu-se por inteiro.

Até mesmo a luz do diamante findou cegando-se no longe.

Sua ponta já rombuda tanto chumbo não rompe.

Tanto chumbo como o que cobre todas as coisas aqui fora. Já agora Pernambuco é o que coube a memória.

Já para encontrar Pernambuco o melhor é fechar os olhos e buscar na lembrança o diamante ilusório.

É buscar aquele diamante em que o vi se cristalizar, que rompeu a distância com dureza solar;

refazer aquele diamante que vi apurar-se cá de cima, que de lama e de sol compôs luz incisiva;

desfazer aquele diamante a partir do que o fez por último, de fora para dentro, da casca para o fundo,

até aquilo que, por primeiro se apagar, ficou mais oculto: o homem, que é o núcleo do núcleo do seu núcleo. ${ }^{50}$

O poema descreve a narrativa do campo visual em cinco perímetros sobrepostos. $\mathrm{Na}$ primeira seção do poema, o poeta está dentro de um avião que começa a mover-se em solo. O campo visual deste momento é a pista do aeroporto. Primeiro círculo. $\mathrm{Na}$ segunda seção, o avião inicia o voo. O campo visual é o solo progressivamente em fuga. Apesar da velocidade do avião, a visão permite reconhecer as coisas. Espacialmente, está no espaço aéreo do aeroporto. Segundo círculo. Na terceira seção, o avião se afasta mais do solo. O campo visual não permite reconhecer as coisas, aglomeradas em faixas, formas geométricas. Espacialmente, sobrevoa a cidade de Recife, deixando para trás o Aeroporto Internacional dos Guararapes. Terceiro círculo. Na quarta seção, cresce 
a distância em relação ao solo. O campo visual impede o reconhecimento de formas. Vê a cidade ao longe, em mancha difusa. Espacialmente, já sobrevoa o mar. Quarto círculo. Na quinta seção, o avião atinge a altura máxima. O campo visual não atinge o solo. Nada se vê do avião. Último círculo.

O distanciamento de Recife, que o voo estabelece, provoca, em sentido inverso, um aprofundamento em si mesmo, também em círculos. Como em um espelho inversamente proporcional aos anéis cromáticos do perímetro visual do avião que deixa o solo e ganha altura, o poeta aprofunda-se em si mesmo, estabelecendo uma viagem para dentro. A espessura espacial retratada à janela do avião recobre-se de outra espessura, corporal e pélvica. Sob a aparente viagem de dentro para fora, o poeta faz outra viagem "de fora para dentro, da casca para o fundo". O afastamento do avião é evocado a partir de uma escala de tudo aquilo que deixa para trás representado visualmente. Em outras palavras, trata-se de uma sequência de perdas que vão se aprofundando a perder de vista. Todas as coisas vão se apagando, isto é, tornando-se progressivamente mais distantes, até não serem mais visíveis. Ao fim, terá perdido tudo. Quando as luzes se apagam, isto é, quando a cidade é só lembrança, restará o homem. O ponto final da viagem é o círculo mais profundo. O vazio que lá encontra é uma conquista que só se ganha perdendo tudo. Impossível não lembrar a inversão poética que produziu a folha branca. Aqui, como lá, a faca está presente, pois só aumenta o vazio, isto é, ela corta até não poder mais. Ela corta tudo. Quando não há mais nada a cortar, terá chegado ao fundo. No núcleo de seu núcleo.

\section{Cão sem plumas}

Ancorado em substantivos, o poema "O cão sem plumas" mobiliza uma floresta de símbolos. A partir do rio Capibaribe, fio condutor do poema, há um segundo grupo de imagens ao qual se ligam, em afluência, outros grupos. Esta estrutura de produção de imagens é operada em vários níveis, pois, entre os substantivos principais e secundários, ligam-se outros substantivos, também em grupos. Para fins de simplificação e análise, dividiremos o poema em dois grupos. O primeiro grupo é formado pelos substantivos diretamente associados ao rio Capibaribe, a saber, água, cão, fruta e homem. O segundo grupo está ligado ao primeiro e se abre a novos grupos em forma de raiz ou árvore, conforme a tabela abaixo:

Grupo 1:

Rio - água, cão, fruta, homem. 
Água - chuva, fonte, peixe, mar, areia, praia, terra...

Cão - pássaro, pluma, língua, ventre, olhos, cadela, osso, pedra, dente...

Fruta - árvore, açúcar, mosca, planta, flor, maçã, fome, semente...

Homem - pele, sangue, luta, sonho, vida...

O poema forma um conjunto arbóreo. O rio (imagem 1), está associado à água (imagem 2), onde está a palavra estagnação (água densa, água parada) e seu sub-conjunto de metáforas: hospital, penitenciária, asilo. Este rio, em outro ramo da árvore, está associado à terra (água escura) que, por sua vez, forma o sub-conjunto: lama, lodo, caranguejo; também associado ao mar e seu sub-conjunto: ostra, mucosa, polvo, etc. A associação das imagens é feita pela técnica de "palavra puxa palavra", de forma arborescente e com repetições, que visam o reforço das imagens. Assim, a palavra peixe puxa a palavra faca. A palavra pluma puxa a palavra barba, que, por sua vez, puxa a palavra cabelo, que puxa a palavra estopa, etc.

Ora, o que liga o primeiro grupo ao segundo é o conceito de profundidade. Há uma diferença de grau ou de valor semântico entre as imagens, como se, a partir da espessura de cada coisa, encontrássemos algo oculto em sua superfície. As imagens do primeiro grupo ocupam o topo da cadeia hierárquica porque representam o fundo, isto é, a última camada do processo de escavação poética. Escavando, o poeta vai do superficial ao profundo, descobrindo, dentro de cada coisa, algo mais profundo:

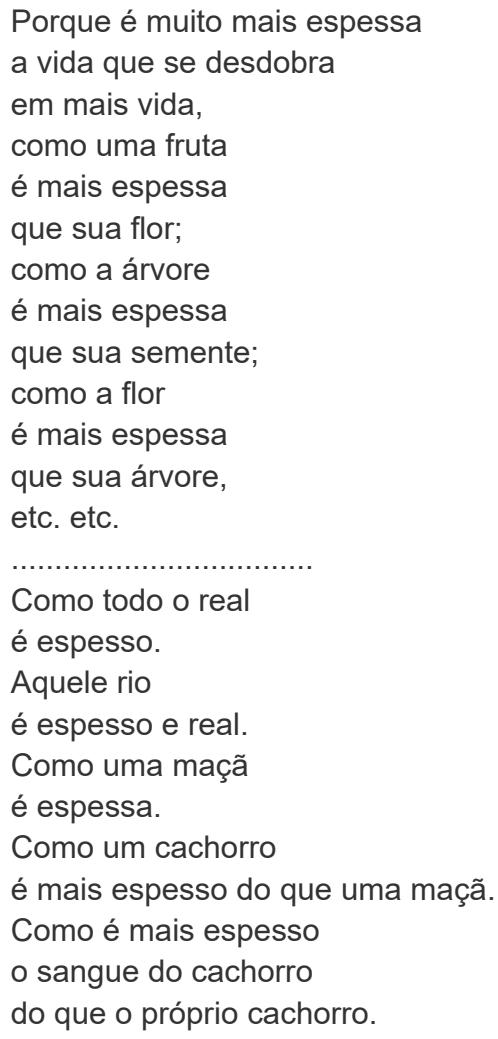




\author{
Como é mais espesso \\ um homem \\ do que o sangue de um cachorro. \\ Como é muito mais espesso \\ o sangue de um homem \\ do que o sonho de um homem.
}

\author{
Espesso \\ como uma maçã é espessa. \\ Como uma maçã \\ é muito mais espessa \\ se um homem a come \\ do que se um homem a vê. \\ Como é ainda mais espessa \\ se a fome a come. \\ Como é ainda muito mais espessa \\ se não a pode comer \\ a fome que a vê.
}

Mas isso não é tudo. O poema é estruturado em função de uma escala de valores. Tratase de saber qual é a mais profunda entre as imagens, isto é, qual é a mais importante. Entretanto, ao contrário da prática rigorosa de cortar até não poder mais, aqui o poeta nada corta, só acrescenta. O processo de escavação é obliterado a partir de uma ambiguidade fundamental entre as imagens:

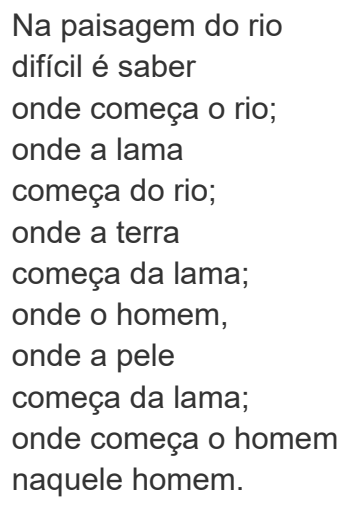

No poema "O cão sem plumas", o adjetivo espesso/espessa aparece 29 vezes! O conceito de espessura (ou de profundidade, pois são sinônimos!) reflete a composição do poema em dois sentidos, tanto na intenção quanto na forma. Tanto no espírito quanto na letra. Já vimos como a lógica do poema é edificada a partir de uma estrutura arbórea em torno de imagens principais às quais se ligam, por afunilamento, outras imagens. $O$ gesto de retirar uma imagem de dentro de outra imagem aparece literalmente nos seguintes versos: "Liso como o ventre/ de uma cadela fecunda/ o rio cresce/ sem nunca explodir. Tem, o rio, um parto fluente e invertebrado/ como o de uma cadela". Efeito de "palavra puxa palavra", presente em "ventre", "cadela", "fecunda" e "parto", o sentido dos 
versos aponta para o fenômeno da gestação. No fundo de um ser, outro ser. Dentro do homem, o cão. É neste sentido que o conceito de profundidade possui dimensão ontológica, pois a natureza do homem é iluminada pela natureza do cão. Seja no plano lexical, seja no plano semântico, estamos diante de um poema de grandeza filosófica ${ }^{51}$, dado o alcance das imagens. O fundamento da natureza humana é a privação, pois, segundo a caixa de Pandora, o homem não tem predicados ou dotes garantidos por essência. Privado de asas, não tem plumas. O poema visa o não ser do homem. Como observou Benedito Nunes, este homem não é um ser qualquer, mas é um ser negado:

Todo ser violentado, cujos atributos se truncam e se confundem, é um cão sem plumas. Exposto a uma geral corrosão, ele é natureza desfalcada. Sua forma de existir é não-ser, pois que só existe como realidade negada em si mesma. O que a nega e desrealiza, até fundi-la com o rio, é uma potência anônima que tem a força opaca, viscosa, pobremente fecunda e estagnada das águas do Capibaribe. O rio conhece os homens sem plumas, seus homônimos, que vão nele perder-se numa convivência de suas naturezas idênticas, ambas corroídas e desfalcadas, ambas se confundindo na dissolução comum, que humaniza o rio e fluvializa o homem. ${ }^{52}$

Em outras palavras, o cão sem plumas é resultado de um processo de identificação negativa, pois simboliza, com a imagem do cão e seus afluentes (pluma, dente, osso, etc.), o dilaceramento, a submissão, a fome, a violência, etc; com a imagem do rio e seus afluentes (lama, lodo, pântano, etc), a morte, o podre, o sujo, etc. Mas essa dupla filiação negativa, de cão e de água densa, não esgota a imagem humana. A identificação com a fruta é uma falha no coração do diamante. Como aponta Benedito Nunes: "Pela sua própria natureza carente, pela corrosão e privação que qualificam sua maneira de existir, a realidade humana, concentrada na imagem do cão sem plumas, é uma realidade espessa e contundente, cortante e agressiva, capaz de firmar-se a si mesma, rejeitando a negação que a reduz ao não ser". ${ }^{53}$ Com a imagem da fruta e seus afluentes (flor, açúcar, maçã, semente, árvore, etc.) dá-se a vida que rebenta, seja como for. $\mathrm{Na}$ obstinação persistente e continuada de cada dia o homem vence, pela luta, a negação. Tal como um pássaro, paradoxalmente, erguendo-se do chão.

\section{bibliografia complementar}

BARBOSA, J. A. A biblioteca imaginária. São Paulo: Ateliê Editorial, 1996.

VALÉRY, P. Variedades. Organização de João Alexandre Barbosa. Tradução de Maiza Martins Siqueira. São Paulo: Iluminuras, 1999.

\section{* Cristiano Perius é professor do Departamento de Filosofia da UEM.}

1 MELO NETO, J. C. Obra completa. Volume único. Organizado por Marly de Oliveira. Rio de Janeiro: Nova Aguilar, 1994. PS, p. 43. As citações da poesia de João Cabral seguem a edição das obras completas, segundo o modelo a seguir: Título da coletânea, conforme tabela a seguir, seguido pelo número de página correspondente: "Pedra do sono": PS; "Psicologia da composição": 
PC; "A educação pela pedra": EP; "Engenheiro": EN; "Quaderna": QU; "Poesia": PO; "Serial”: SE; "Paisagem com figuras": PF; "Uma faca só lâmina": FL; "Dois parlamentos": DP; "O cão sem plumas": CS.

2 ANDRADE, C. D. Poesia completa. Rio de Janeiro: Ed. Nova Aguilar, 2002, "Poema de sete faces", p. 23.

3 PC, p. 93.

4 PC, p. 94.

5 PC, p. 96.

6 PC, p. 96.

7 HEIDEGGER, M. "Carta sobre o humanismo". In: Conferências e escritos filosóficos. Tradução de Ernildo Stein. São Paulo: Abril Cultural, 1979, p. 149.

8 PC, p. 97.

9 PC, p. 95.

10 EN, p. 79.

11 REBUZZI, S. O idioma pedra de João Cabral. São Paulo: Perspectiva, 2010, p. 30.

12 NUNES, B. João Cabral: A máquina do poema. Organização de Adalberto Müller. Brasília: Editora Universidade de Brasília, 2007, p. 131.

13 EN, p. 83.

14 EP, p. 338.

15 EP, p. 336.

${ }^{16}$ A outra fonte privilegiada é Sevilha, em virtude da carreira diplomática do poeta.

17 NUNES, B. Op. cit., p. 18.

18 SARTRE, J.-P. Situações I. Tradução de Cristina Prado. São Paulo: Cosac Naify, 2005, p. 240.

19 PO, p. 120.

20 QU, p. 255.

21 EN, p. 79.

22 NUNES, B. Op. cit., p. 122.

23 QU, p. 256.

24 QU, p. 259.

25 QU, p. 258.

26 NUNES, B. Op. cit., p. 87.

27 PEIXOTO, M. Poesia com coisas. São Paulo: lluminuras, 1997, p. 153.

28 PONGE, F. A mesa. Tradução e apresentação de Ignácio Antonio Neis e Michel Peterson. São Paulo: Iluminuras, 2002, p. 307 (Edição bilíngüe). 
29 “Francis Ponge, outro cirurgião,/ adota uma outra técnica:/ gira-as nos dedos, gira/ ao redor das coisas que opera.// Apalpa-as com todos os dez/ mil dedos da linguagem/ não tem bisturi reto/ mas um que se ramificasse.// Com ele envolve tanto a coisa/ Que quase a enovela/ E quase a enovelando,/ Se perde, enovelado nela" (SE, p. 298).

30 PONGE, F. Oeuvres completes, v. 1. Paris: Gallimard, 1999, p. 807 (Bibliothèque de la Pléiade).

31 REBUZZI, S. Op. cit., p. 100.

32 QU, p. 251.

33 PC, p. 93.

34 PF, p. 164.

35 PF, p. 163.

36 FL, p. 207.

37 Em "Psicologia da composição", o poema é escrito às avessas. Veremos "De um avião" e "O cão sem plumas" a seguir. Há outros exemplos: "Fez o caminho inverso:/ do vapor à gota de água/ (não, da vida ao sono,/ ao sonho, ao santo);/ foi da palavra à coisa” (MT, p. 411).

38 EF, p. 429.

39 DP, p. 288.

40 MERLEAU-PONTY, M. O visível e o invisível. Tradução de José Artur Gianotti e Armando Mora de Oliveira. São Paulo: Perspectiva, 1992, p. 200.

41 Idem. Le visible et I'invisible. Paris: Gallimard, 1964, p. 188.

42 Ibidem, p. 19.

43 DP, p. 282.

44 EP, p. 357.

45 NUNES, B. Op. cit., p. 10.

46 Ibidem.

47 MERLEAU-PONTY, M. \$ITALICO\$O visível e o invisível_\$ITALICO\$. Op. cit., p. 202.

48 Ibidem, p. 133.

49 Ibidem, p. 199.

50 QU, p. 232.

51 Poder-se-ia estabelecer um paralelo entre a natureza do cão e a filosofia de Sartre. Não necessariamente. Melhor em aberto, a dimensão poética das imagens não tem equivalentes.

52 NUNES, B. Op. cit., p. 48.

53 Ibidem, p. 49. 